\title{
Detection of Potential Eco-friendly Microbes to Clean-Up the Polluted Water in Sri Lanka
}

\author{
K. Vivehananthan", Y. W. Manukulasooriya and \\ W. M. J. Y. Ekanayake \\ Dept. of Biotechnology \\ Faculty of Agriculture and Plantation Management \\ Wayamba University of Sri Lanka \\ Makandura, Gonawila (NWP), Sri Lanka \\ ${ }^{\#}$ Corresponding Author: \\ Tele: (94) 77398 8612; Fax: (94) 31229 9248; E-mail: kalaivani@wow.lk
}

\begin{abstract}
Microbial biodegradation of pollutants has intensified in recent years as mankind strives to find sustainable ways to clean up contaminated environments. These biological processes play a major role in the removal of contaminants in the polluted environment. Utilization of catabolic versatility of naturally occurring microorganisms in biodegrading processes is an essential process to degrade or convert such compounds. Recent developments in molecular microbial ecology offer new tools that facilitate molecular analyses of microbial population at contaminated sites. Both conventional and the molecular methods were used in this study to identify the bacteria from different polluted environments. Bacteria were isolated from the rubber latex contaminated water, municipal waste, petroleum waste and agricultural waste. Then, microbial DNA was isolated and amplified with Pseudomonas aeruginosa specific primers. The amplification of $162 \mathrm{bp}$ specific region of catabolic gene of Pseudomonas aeruginosa confirmed the presence of this organism in the contaminated water collected from different climatic regions in Sri Lanka.
\end{abstract}

KEYWORDS: Biodegradation, Polluted water, Pseudomonas aeruginosa

\section{Introduction}

Environmental pollution is increased as a consequence of industrialization in all over the world. Thousands of hazardous waste sites have been generated worldwide resulting from the accumulation of xenobiotics in soil and water over the years. Increment of this pollution caused many hazards for all organisms, even for humans such as carcinogenicity and toxicity. The elimination of wide range of pollutants and waste from the environment is an absolute requirement to promote a sustainable development of our society with low environmental impact. 
Bioremediation provides an alternative to chemical treatments.Bioremediation uses naturally occurring microorganisms to degrade various types of wastes. Contaminants are often potential energy sources for microorganisms. Microorganisms survive in contaminated habitat because they are metabolically capable of utilizing its resources (Lovley, 2003). Like all living creatures, microbes need nutrients, carbon, and energy to survive and multiply. Such organisms are capable of breaking down chemicals to obtain food and energy, typically degrading them into harmless substances such as carbon dioxide, water, salts, and other innocuous products.

The aim of this work is to isolate the bacteria from contaminated sites to assess their potential for bioremediation to develop a byproduct useful for bioremediation purposes.Traditional culture dependent methods are insufficient to isolate many microorganisms from the ecological niche (Hugenholtz et al., 1998; Martin Laurent et al., 2001; Allan et al., 2005). Therefore, it is necessary to explore bioremediation agents using modern molecular approach to overcome the limitation factors involved in poor cultivability of microbes (Phoebe et al., 2001).

\section{Materials and Methods}

\section{Bacteria and Culture}

Bacteria were isolated from the rubber latexcontaminated water which was collected from the area of industrial zone. The water sample were streaked in nutrient agar medium and incubated at $37^{\circ} \mathrm{C}$ for $24 \mathrm{hr}$. Bacterial isolates were selected based on the colour, shape and the morphology of the colonies. To test for the utilization of rubber latex particles by these bacteria, the selected bacterial isolates were grown in enrichment medium containing latex.

\section{Enrichment for Bacterial Isolates}

The enrichment culture was prepared by the addition of rubber latex to the nutrient agar broth medium. Selected bacterial isolates were pre cultivated in nutrient broth for overnight. Nutrient agar broth was centrifuged at high speed for $10 \mathrm{~min}$. Pellet was washed in saline water (3\%), re-suspended in $4 \mathrm{ml}$ saline and was used as the inoculum at $3 \% \mathrm{v} / \mathrm{v}$ concentration. Nutrient broth medium containing $3 \%$ latex was used as the sole source of carbonto be used as diluents. Latex dilutions (1:1000, 1:500, 1:200, and 1:100) were used. In addition inoculum $(0.3 \mathrm{ml})$ from each of these selected isolate was added to the nutrient broth and incubated separately on a rotary shaker at $120 \mathrm{rpm}$ for 12 days. The bacterial isolates which grew in the latex dilution were selected. The selected strains were then grown in $5 \mathrm{ml}$ of $100 \%$ latex for $48 \mathrm{hr}$ in the shaker at $120 \mathrm{rpm}$. 


\section{Bacterial Identification}

Microbial properties of the isolates were determined by gram staining and catalase test. Bacteria smear was stained with crystal violet for 2 min followed by gram's iodine for $1 \mathrm{~min}$ and thensafranin for $1 \mathrm{~min}$. Catalase activity of the bacterial isolates were tested with $3 \% \mathrm{H}_{2} \mathrm{O}_{2}$. Identification of isolates present in different sources of wastewater was also performed by DNA analysis.

\section{Bacterial Identification by DNA Based Methods}

Bacterial cultures isolated from industrial effluent and wastewater collected from contaminated water withmunicipal, petroleum, industrial and agricultural wastefrom two differentclimatic zones, especially the wet zone (Colombo) and the intermediate zone (Kurunagala) were used for the DNA extraction. For each DNA extraction, two different protocols were used. In the first protocol, DNA was extracted from the bacterial culture obtained from the wastewater contaminated with the rubber latex. The second protocol was performed based on the method described for DNA extraction directly from wastewater (Chaudhuri et al., 2006).

\section{Genomic DNA Extraction from Bacteria}

In the first protocol, the lysis step was performed by adding $10 \mu 1$ of $1 \%$ SDS to $800 \mu \mathrm{l}$ of bacterial suspension and a gentle rotation was done for approximately 5 min. Then the bacterial suspension was kept in a water bath at $65^{\circ} \mathrm{C}$ for $30 \mathrm{~min}$ and left to cool to room temperature.Stirring rod was placed into the lysed bacterial suspension and ice cold $100 \%$ ethanol was added slowly down the stirring rod and rod was rotated for $5 \mathrm{~min}$. Rod with bacterial DNA was immersed in $70 \%$ ethanol for $2 \mathrm{~min}$. Then DNA was dissolved in $300 \mu \mathrm{l}$ of TE buffer. Equal volume of chloroform was added to the DNA sample and mixed well. Mixture was centrifuged at high speed for $1 \mathrm{~min}$ at room temperature. Aqueous phase was transferredinto a fresh tube. This procedure was repeated twice to separate the aqueous phase. DNA was precipitated by addition of $100 \%$ ethanol and centrifugation. Ethanol was removed and pellet was air-dried. DNA was dissolved in $20 \mu \mathrm{l}$ of TE buffer and was stored at $-20^{\circ} \mathrm{C}$.

The second protocol was performed based on the method described for DNA extraction directly from wastewater (Chaudhuri et al., 2006) (see below). For visualizing the DNA extracts, each extract was electrophoresed on $0.8 \%$ agarose gel in 1xTBE buffer, stained with ethidium bromide and examined under ultraviolet (UV) light.

\section{Microbial DNA Extraction from Wastewater}

In the second protocol, wastewater obtained from industrial, municipal, petroleum and agricultural waste was enriched with glucose $(10 \mathrm{~g} / \mathrm{L})$ by keeping overnight in 
the shaker and then DNA was directly extracted by the modified direct extraction method.

The wastewater sample was centrifuged to pellet down the cells at high speed for 15 min. This was performed three times to pool the pellet. The pellet was washed twice with wash buffer (50 mMTrisHCl, $\mathrm{pH} 8.00,5 \mathrm{mM}$ EDTA, $\mathrm{pH} 8.00$ ) before lysis. The pellet was dissolved in $500 \mu \mathrm{l}$ lysis buffer (100 mMTrisHCl, pH 8.00, $100 \mathrm{mM}$ EDTA, pH 8.00, $1.5 \mathrm{M} \mathrm{NaCl}$ ) and centrifuged at high speed for $15 \mathrm{~min}$. Supernatant was separated and $75 \mu \mathrm{l} \mathrm{NaOAC}$ and $500 \mu \mathrm{l}$ of ice cold isopropanol were added and centrifuged at high speed for 15 min. Pellet was washed with $70 \%$ ethanol. Ethanol was removed and pellet was air-dried until ethanol was evaporated. Then the pellet was resuspended in $25 \mu \mathrm{l}$ of deionized water. Extracted DNA was electrophoresed on $0.8 \%$ agarose gel containing ethidium bromide and visualized under UV light.

\section{Test Organism}

To screen for the presence of the bioremediation agent in contaminated water in Sri Lanka, specific primerswere designed and used to identify the bacteria Pseudomonas aeruginosaas it is acommon bacteria having biodegrading ability, present in all types of waste in all part of the world (Ekanayakeet al., 2010).

\section{PCR Amplification}

A region $162 \mathrm{bp}$ from the catabolic gene of dimethylglycinewas amplified using the forward primer and F 5'GAACGTGCTGGTCTACGACA3' and the reverse primerR5'GGGATACATGCTGCGGTAGT3'. Each $20 \mu 1$ PCR mixture contained 40 ngDNA, $200 \mu \mathrm{M}$ dNTPs, $0.7 \mu \mathrm{M}$ each of two opposing primers, 1X PCR buffer, $2.5 \mathrm{mM} \mathrm{MgCl}_{2}$ and 0.8 units of Taq polymerase. The amplification cycle consisted of an initial denaturation step of $5 \mathrm{~min}$ at $94^{\circ} \mathrm{C}$ followed by 30 cycles of $1 \mathrm{~min}$ at $94^{\circ} \mathrm{C}, 1 \mathrm{~min}$ at $58^{\circ} \mathrm{C}, 1 \mathrm{~min}$ at $72^{\circ} \mathrm{C}$ and the final extension step of $10 \mathrm{~min}$ at $72^{\circ} \mathrm{C}$ was included. Final holding temperature was $4^{\circ} \mathrm{C}$. Template DNA was omitted from the reaction mixture for the negative control. Amplified PCR products were electrophoresed on $1 \%$ agarose gel containing ethidium bromide and visualized under ultraviolet light.

\section{Results and Discussion}

\section{Isolation and Characterization of Bacteria from Industrial Effluent}

Bacteriaisolated from the industrial effluent by enrichment culture with rubber latex were screened for the latex degrading ability. The isolates that could grow on liquid medium with higher concentration of latex (100\%) were selected as the most efficient isolates for the degradation of natural rubber latex (data not shown).

Most of these bacterial isolates screened for this study, were white in colour and appeared bluish in colour under the direct light and negative for gram staining and 
positive for the catalase test. Most aerobic organism makes catalase. Based on its morphological and biochemical properties, these isolates were identified as gram negative and aerobic. They found to be characteristics of Pseudomonas aeruginosa. In order to identify this bioremediation organism in contaminated sites from different climatic zones and from different types of wastewater, the microbial populations in wastewater were screened by DNA based techniques. Therefore, genomic DNA was first isolated and then subjected to PCR amplification using species specific primers.

\section{Extraction of Microbial DNA}

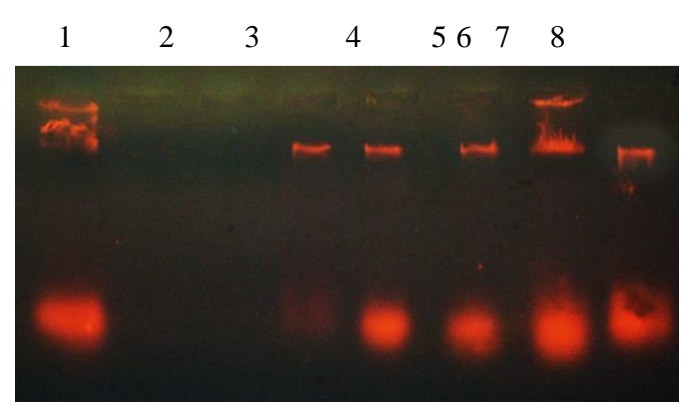

Figure 1: Extraction of Genomic DNA from Bacteria using Protocol 1

Lane 1-8: DNA isolated from different Bacterial colonies

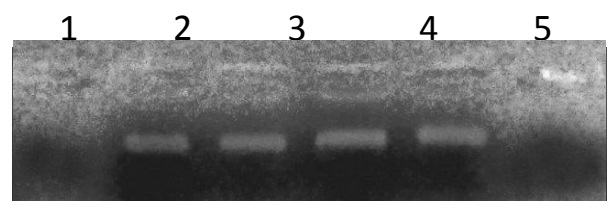

Figure 2: Extraction of Microbial DNA from Wastewater

Lane 1: DNA directly isolated from wastewater. Lane $2-5$ : DNA isolated from optimized wastewater samples (Lane 2: Municipal waste, Lane 3: Petroleum waste, Lane 4: Industrial waste and Lane 5: Agricultural waste). Lane 6: Negative control.

DNA extracted from bacterial culture bythe first protocols provided a good yield of DNA which could be used in PCR amplification (Figure 1).Direct lysis for DNA extraction by optimization with glucose proved to be very efficient in providing large amounts of DNA from environmental samples (Figure 2) while DNA extraction without optimization was not efficient. All extraction products obtained by different protocols could be amplified with the primers specific for Pseudomonasaeruginosa. Satisfactory amplified products were obtained indicating that the DNA was good in quality in all the DNA preparations and the DNA samples were free of PCR inhibitors.

\section{PCR Amplification of Catabolic Gene Fragment}

PCR amplification was performed to detect the $162 \mathrm{bp}$ region of catabolic gene in Pseudomonas aeruginosausing specific primers. The amplified band was observed between $564 \mathrm{bp}$ and $125 \mathrm{bp}$ region of the lambda ladder, confirming the presence of expected PCR product (Figure 3). The absence of band innegative control explained the reliability of the PCR reaction. However further confirmation is recommended. This could be possible by sequencing the amplified product. 


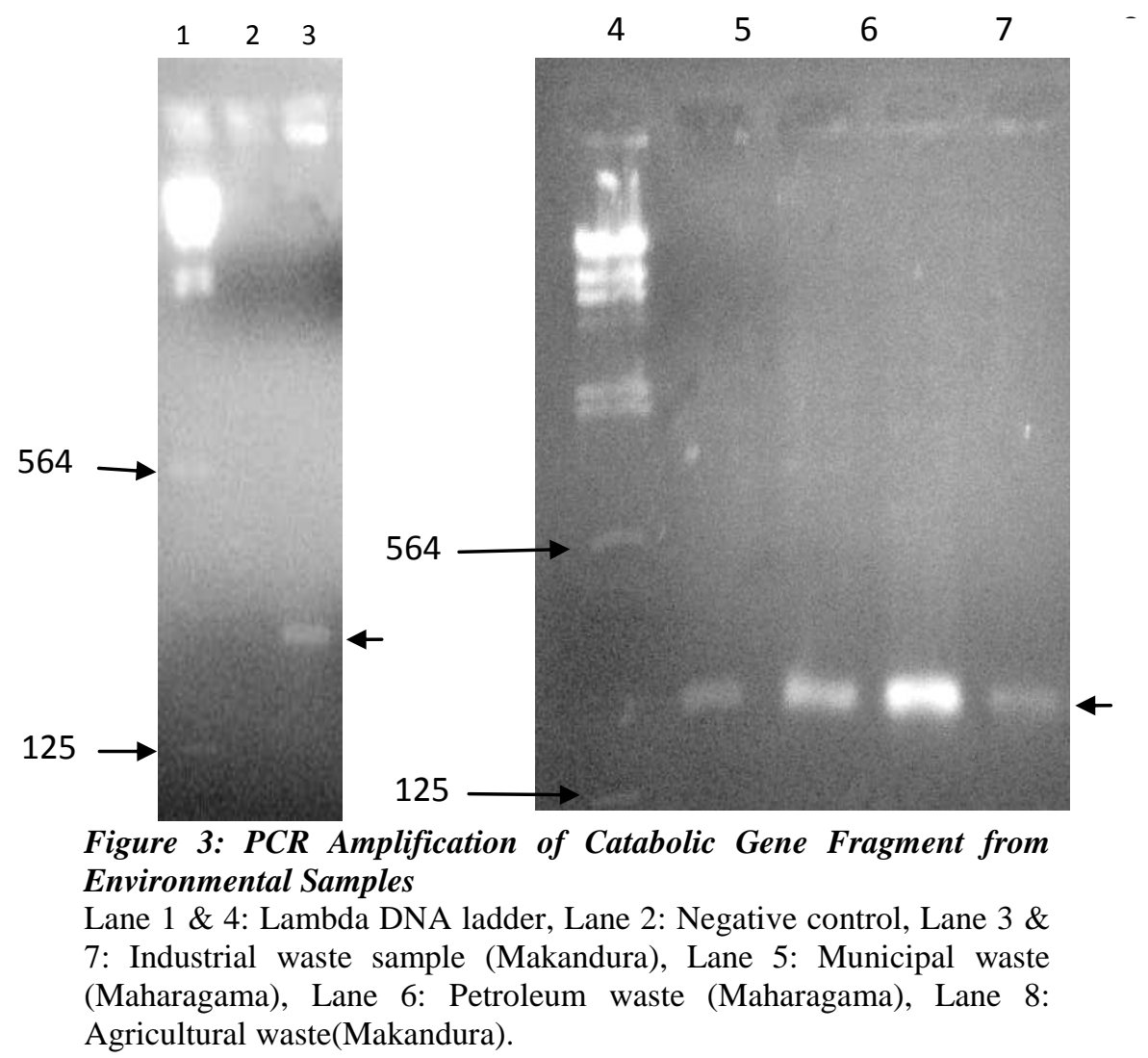

\section{Conclusions}

Bacteria isolated from industrial effluent were able to grow and degrade natural rubber latex effectively. These bacterial isolates were identified as gram negative and aerobic. DNA extracted from both bacterial culture and directly from wastewater was good in quality and suitable for PCR amplification. However, DNA extracted directly from wastewater gave high yield of DNA when wastewater was enriched with glucose. The bacterium Pseudomonas aeruginosawas identified from various typesof contaminated sites in different parts of the island. Further confirmation is required for the detection of this organism. This study should be extended to identify the potential bioremediation organism from other regions of the country.

\section{References}

Allan, R. N., L. Lebbe, J. P. Heyrman, P. De Vos, C. J. Buchanan and N. A. Logan (2005). "Brevibacilluslevickii sp. nov. and Aneurinibacillusterranovensis sp. nov. two novel thermoacidophiles isolated from geothermal soils of Northern Victoria Land, Antarctica" International Journal of Systematic and Evolutionary Microbiology, 55: 1039 - 1050. 
Chaudhuri, S. R., A. K. Pattanayak and A. R. Thakur (2006). "Microbial DNA extraction from samples of varied origin" Current Science, 91(12): 1697 - 1700.

Ekanayake, W. M. J. Y., K. Vivehananthan and T. Wickramarachchi (2010). "Identification and classification of xenobiotic degrading bacteria in different waste types" Proceedings of the $10^{\text {th }}$ Agricultural Research Symposium, Wayamba University of Sri Lanka, 65 - 69.

Hugenholtz, P., B. M. Goebel and N. R. Pace (1998). "Impact of culture independent studies on the emerging phylogenetic view of bacterial diversity" Journal of Bacteriology, 180: 4765 - 4774.

Lovley, D. R. (2003). "Cleaning up with Genomics: Applying molecular biology to bioremediation" Nature Review, 1: 35 - 44.

Martin, L. (2001). "DNA extraction from soils: Oil bias from new microbial diversity analysis methods" Applied Environmental Microbiology, 67: 2354 - 2359.

Phoebe, Jr. C. H., J. Combie, F. G. Albert, K. Van Tran, J. Cabrera and H. J. Correira (2001). "Extremophilic organisms as an unexplored source for antifungal compounds" Journal of Antibiotics, 54: 56 - 65. 